\title{
Effects of matcha tea extract on cell viability and peroxisome proliferator-activated receptor $\gamma$ expression on T47D breast cancer cells
}

\author{
Simon Keckstein ${ }^{1}$. Constantin Tilgener ${ }^{1,2} \cdot$ Udo Jeschke $^{1,3}$ - Simone Hofmann ${ }^{1}$ - Theresa Vilsmaier ${ }^{1}$. Till Kaltofen ${ }^{1}$. \\ Helene Heidegger ${ }^{1} \cdot$ Falk Batz $^{1}$. Sven Mahner ${ }^{1}$. Lennard Schröder ${ }^{1}$
}

Received: 14 October 2021 / Accepted: 23 December 2021 / Published online: 25 January 2022

(c) The Author(s) 2022

\begin{abstract}
Purpose In the following work, we investigated the nuclear peroxisome proliferator-activated receptor gamma (PPAR $\gamma$ )dependent proliferation behavior of breast cancer cells after stimulation with matcha green tea extract (MTE).

Methods T47D cells were stimulated with MTE at concentrations of 5, 10 and $50 \mu \mathrm{g} / \mathrm{ml}$. Cell viability was assessed using a WST-1 assay after an incubation time of $72 \mathrm{~h}$. PPAR $\gamma$ expression was quantified at the gene level by real-time polymerase chain reaction (PCR). A western blot (WB) was carried out for the qualitative assessment of the expression behavior of on a protein level.

Results The WST- 1 test showed a significant inhibition of viability in T47D cells after $72 \mathrm{~h}$ at 5,10 and $50 \mu \mathrm{g} / \mathrm{ml}$. The PCR showed an overexpression of PPAR $\gamma$ in T47D cells in all concentrations. At the concentration of $50 \mu \mathrm{g} / \mathrm{ml}$ the expression was significantly increased $(p<0.05)$. The WB demonstrated a significant quantitative increase of PPAR $\gamma$ at protein level with MTE concentrations of 10 and $50 \mu \mathrm{g} / \mathrm{ml}$. In addition, there was a negative correlation between the overexpression of PPAR $\gamma$ and the inhibition of proliferation.

Conclusion MTE decreases the cell viability of T47D cells and furthermore leads to an overexpression of PPAR $\gamma$ on protein and mRNA level.
\end{abstract}

Keywords Matcha tea extract $\cdot$ MTE $\cdot$ T47D $\cdot$ PPAR $\gamma \cdot$ WST- $1 \cdot$ PCR $\cdot$ Western blot

\section{Introduction}

Breast cancer is the most frequent cancer in women worldwide. Increases in incidence over the last decades have been linked to the implementation of screening programs [1]. In 2018, around 2.1 million new cases were diagnosed worldwide and 626,679 women died of breast cancer [2]. Modern multimodal therapeutic concepts have enabled cure rates of

Udo Jeschke

Udo.Jeschke@med.uni-muenchen.de

1 Department of Obstetrics and Gynecology, University Hospital, LMU Munich, Marchioninistr. 15, 81377 Munich, Germany

2 Department of Urology and Transplant Surgery, Klinikum Stuttgart, Kriegsbergstraße. 60, 70174 Stuttgart, Germany

3 Department of Obstetrics and Gynecology, University Hospital Augsburg, Stenglinstr. 2, 86156 Augsburg, Germany
70-80\% [3]. To achieve further improvements, the investigation of mechanisms and possible substances that may inhibit cancer proliferation and invasion remains of interest. Second only to water, tea is the most commonly consumed beverage worldwide [4] and in western countries its popularity is increasing further. Like black and green tea (GT), matcha tea (MT) is obtained from the leaves of the tea plant Camellia sinensis. While with GT the tea leaves are removed from the tea before consumption, with MT they are ground into a fine powder, dissolved in boiling water and ingested in their entirety; therefore, the intake of various substances contained in the leaves is much higher [4-6]. MT contains polyphenols, including the subdivisions of flavonoids, flavanols and catechins. Up to $30 \%$ of the dry mass of fresh tea leaves is made up of phenolic compounds, $90 \%$ of which are catechins. Of the catechins found in MT, epigallocatechin gallate (epigallocatechin-3-gallate, EGCG) is most abundant [7]. Other catechins such as epigallocatechin (EGC), epicatechin gallate (ECG) and epicatechin (EC) only make up 
$10 \%$. The remaining dry mass components in tea leaves are proteins $(15 \%)$, amino acids (4\%), caffeine (4\%), raw fibers (26\%), lipids (7\%), other carbohydrates (7\%), pigments, such as chlorophyll and carotenoids (2\%) and minerals (5\%) [8]. $100 \mathrm{ml}$ of GT contains approximately 20-100 mg of EGCG [9]. The main limitation for broad therapeutic application of polyphenols is that after oral intake and metabolism only as little as $0.024 \%$ are bioavailable $[10,11]$. Results of pharmacokinetic studies concluded that after ingestion, EGCG concentrations in human serum may reach no more than the high nanomolar range [12]. The concentrations we used in vitro in the study presented here are deliberately lower than those used in previous experiments, but still substantially higher than serum concentrations measured in vivo after consumption and metabolism by humans. EGCG has been extensively investigated for its tumor inhibitory effects in breast and prostate cancer [13-16]. Different mechanisms by which EGCG can influence the cell cycle and proliferation have been described, such as the inhibition of matrix metalloproteinases [17], Wnt signaling [18], methylation [19] and induction of peroxisome proliferator-activated receptors (PPAR) [20-22]. The PPAR family of essential nuclear receptors includes three subtypes $(\alpha, \beta / \delta$, and $\gamma)$ that bind directly to certain DNA regions and regulate the expression of target genes [23]. Previous research suggests that PPAR $\gamma$ has a pivotal role in the pathophysiology of multiple diseases and possibly their treatment. For instance, PPAR $\gamma$ is one of the major transcription factors activated by thiazolidinediones [24]. Research on PPAR $\gamma$ in tumor cells has yielded divergent results; in some studies it acted as a tumor suppressor, but others reported growth-promoting effects [25-28]. Investigations regarding breast cancer report mostly tumor suppressing effects [27, 29, 30]. With current data supporting that Camellia sinensis has a tumor suppressing effect on breast cancer cells, we wanted to elucidate a possible involvement of PPAR $\gamma$. With diverging results of a possible cell inhibitory effect of EGCG on T47D [31, 32], we, therefore, investigated the effect of MTE in different concentrations on T47D breast cancer cells. Cell proliferation was analyzed using the WST- 1 array. PPAR $\gamma$ expression was measured via real-time PCR and PPAR $\gamma$ protein levels were determined via western blot.

\section{Materials and methods}

\section{Cell cultivation and cell stimulation}

To mimic ductal breast carcinoma, the T47D cell line was used. Cells were grown on $80 \%$ monolayer in a cell culture bottle and cultivated in Dulbecco's Modified Eagle Medium (DMEM; 3.7 g/L NaHCO3, 4.5 g/L D-glucose, 1.028 g/L stable glutamine, and sodium pyruvate; Biochrom, Berlin,
Germany). Then $10 \%$ heat-inactivated fetal calf serum (FCS; Biochrom) was added to the medium and incubated with atmospheric concentrations of $\mathrm{CO}_{2}$ of $5 \%$ at $37^{\circ} \mathrm{C}$. For further use they were trypsinized and counted.

\section{Preparation of the matcha tea extract (MTE)}

Matcha tea was purchased commercially (Houjo Matcha Tea, harvested in Hoshino, Yame prefecture, Japan). For each test, the tea extract preparation was done as described in each test below.

\section{WST-1 assay}

T47D cells were cultivated in a 96-well plate at a density of 10,000 cells per well in $50 \mu \mathrm{l}$ DMEM with $10 \%$ FCS. After $4 \mathrm{~h}$, the medium was replaced with DMEM without FCS. FCS is known to contain substances affecting cell proliferation and maintenance such as growth factors, hormones, vitamins, and transport proteins. By using DMEM without FCS, a possible effect of FCS components on cell proliferation was reduced [33, 34]. Cells were incubated for a further $12 \mathrm{~h} .27 .1 \mathrm{mg}$ tea extract were dissolved in $100 \mu \mathrm{l}$ pure ethanol and diluted 1:1000 with DMEM without FCS. A control solution was prepared in the same way without adding MTE. Afterwards, different amounts of the MTE solution and DMEM without FCS were added to achieve the desired concentrations $(5,10$ and $50 \mu \mathrm{g} / \mathrm{ml})$, resulting in a total of $100 \mu \mathrm{l}$ per well. For the control group, instead of the MTE solution, the control solution and DMEM without FCS were added to each well. The wells were then incubated for $72 \mathrm{~h}$. After incubation, the WST-1 reagent (water soluble tetrazolium, 4-[3-(4-iodophenyl)-2-(4-nitrophenyl)-2H-5-tetrazolio]-1,3benzene disulfonate; Sigma-Aldrich, St. Louis, MO, USA) was added to detect the activity of mitochondrial succinate dehydrogenase cleaving the tetrazolium salt to formazan. Cell viability was measured after incubating for $30 \mathrm{~min}$ with the use of a multi-well spectrophotometer (wavelength: 420-480 nm). Three independent measurements with three technical replicates were performed.

\section{PCR}

T47D cells were incubated on a 12 -well plate at a density of 500,000 cells per well for $4 \mathrm{~h}$ with $500 \mu \mathrm{LMEM}$ with $10 \%$ FCS. Then the medium was replaced with $500 \mu \mathrm{l}$ DMEM without FCS and the cells were incubated for a further $12 \mathrm{~h}$. $27.1 \mathrm{mg}$ tea extract were dissolved in $100 \mu \mathrm{l}$ pure ethanol and diluted 1:1000 with DMEM without FCS. A control solution was prepared in the same way without adding MTE. Afterwards, different amounts of the MTE solution and DMEM without FCS were added to achieve the desired concentrations $(5,10$ and $50 \mu \mathrm{g} / \mathrm{ml})$, resulting in a total of 
$500 \mu \mathrm{l}$ per well. For the control group, instead of the MTE solution, the control solution and DMEM without FCS were added to each well. The wells were then incubated for two hours. This time was selected because changes in mRNA levels are expected within hours after stimulation and the half-life of mRNA also being in the range of hours. Longer incubation times may, therefore, be unsuitable for detection of short-term changes in mRNA levels. The excess liquid was removed. The wells were washed with phosphatebuffered saline (PBS) and RA-1 buffer (Macherey-Nagel, Düren, Germany) was added for cell lysis. For RNA isolation, the NucleoSpinRNAII (Macherey-Nagel, Düren, Germany) was used. For the reverse transcription of RNA, the High-Capacity cDNA Reverse Transcription Kit (Thermo Fisher Scientific, Waltham, MA, USA) was used. $10 \mathrm{ng}$ of RNA were added. The temperature protocol phases were $10 \mathrm{~min}$ at $25^{\circ} \mathrm{C}, 2 \mathrm{~h}$ at $37^{\circ} \mathrm{C}, 5 \mathrm{~s}$ at $85^{\circ} \mathrm{C}$ and stopped with a cooling phase at $4{ }^{\circ} \mathrm{C}$. For the TaqMan ${ }^{\circledR}$ PCR, 96-well plates with $20 \mu \mathrm{l}$ well volume were used. Each well was filled with $10 \mu \mathrm{l}$ of TaqMan ${ }^{\circledR}$ Universal PCR Master Mix 2X (Thermo Fisher Scientific), $8 \mu \mathrm{l}$ of distilled water treated with $0.1 \%$ diethyl pyrocarbonate (DEPC), $1 \mu$ of TaqMan ${ }^{\circledR}$ Gene Expression Assay 20X (Thermo Fisher Scientific; target: ACTB, assay ID Hs99999903_m1; target: PPARG, assay ID Hs01115513_m1; sequences of the primers not revealed by manufacturer), and $1 \mu \mathrm{l}$ of cDNA sample. The PCR assay was performed using the ABI Prism 7500 Fast (Thermo Fisher Scientific). Thermal cycling was started for $20 \mathrm{~s}$ at $95^{\circ} \mathrm{C}$ and was followed by 40 cycles of amplification at $95{ }^{\circ} \mathrm{C}$ for $3 \mathrm{~s}$, and $60{ }^{\circ} \mathrm{C}$ for $30 \mathrm{~s}$. To analyze the results, the comparative $2^{-\Delta \Delta \mathrm{CT}}$ method was used [35]. As endogenous control for the $\Delta \mathrm{CT}$-values, $\beta$-actin was used. Three independent measurements with two technical replicates were performed.

\section{Western blot}

T47D cells were cultivated in a 12 -well plate at a density of 500,000 cells per well in $1000 \mu \mathrm{l}$ DMEM with $10 \%$ FCS. After $4 \mathrm{~h}$, the medium was replaced with $1000 \mu \mathrm{DMEM}$ without FCS and the cells were incubated for a further $12 \mathrm{~h}$. $20 \mathrm{mg}$ tea extract were dissolved in $100 \mu \mathrm{l}$ pure ethanol and diluted 1:1000 with DMEM without FCS. The dilution for the control cells was prepared in the same way without the addition of MTE. Afterwards, different amounts of the MTE solution and DMEM without FCS were added to achieve the desired concentrations $(5,10$ and $50 \mu \mathrm{g} / \mathrm{ml})$, resulting in a total of $1000 \mu \mathrm{l}$ per well. For the control group, instead of the MTE solution, $250 \mu \mathrm{l}$ control solution and $750 \mu \mathrm{l}$ DMEM without FCS were added to each well. Cells were incubated for $48 \mathrm{~h}$, then washed with phosphate-buffered saline (PBS). For cell lysis, $200 \mu \mathrm{l}$ of a buffer solution consisting of a 1:100 of protease inhibitor (Sigma-Aldrich, St.

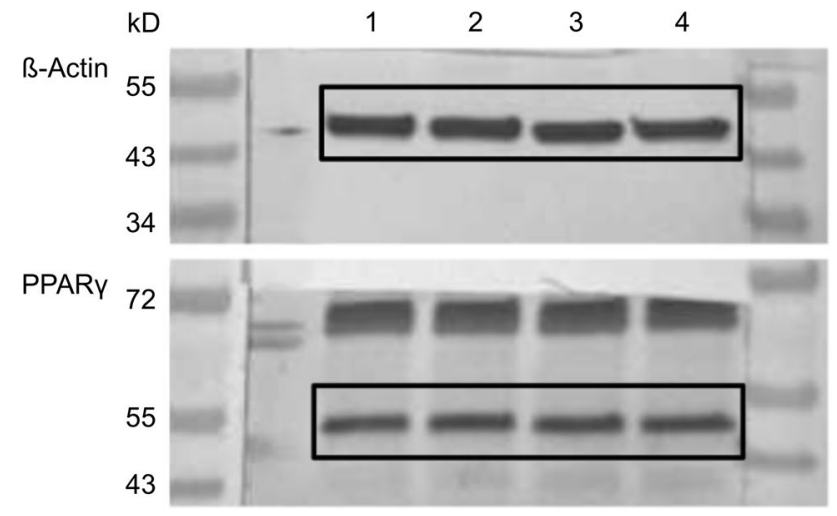

Fig. 1 Example of western blot membranes after stimulation with different concentrations of MTE or the control group and incubation with $\beta$-actin and PPAR $\gamma$ antibodies. The respective bands are numbered [(1) $0 \mu \mathrm{g} / \mathrm{ml}$; (2) $5 \mu \mathrm{g} / \mathrm{ml}$; (3) $10 \mu \mathrm{g} / \mathrm{ml}$; (4) $50 \mu \mathrm{g} / \mathrm{ml}$ ] and marked with black boxes.

Louis, MO, USA) in RIPA buffer (radioimmunoprecipitation assay buffer; Sigma-Aldrich) was added to each well before incubating for $30 \mathrm{~min}$ at $4{ }^{\circ} \mathrm{C}$. After centrifuging the lysates, a Bradford protein assay of the supernatant was performed. With western blotting, the proteins were separated depending on their molecular weight with the use of SDS-PAGE and transferred onto a polyvinylidene fluoride (PVDF) membrane (Merck Millipore, Darmstadt, Germany). After blocking the PVDF membrane for $1 \mathrm{~h}$ in a receptacle containing a casein solution $1 \times$ (Vector Laboratories, Burlingame, CA, USA) to prevent a nonspecific binding of the antibodies, the primary antibodies anti- $\beta$-actin (clone AC-15, mouse IgG; Sigma-Aldrich Co., St. Louis, Missouri, USA) and anti-PPAR $\gamma$ (polyclonal IgG, rabbit, Abcam, Cambridge, UK) were diluted in a $1 \times$ casein solution and afterwards laid onto the membrane for $16 \mathrm{~h}$ at $4{ }^{\circ} \mathrm{C}$. After washing the membranes with tris-buffered saline (TBST), membranes were incubated with biotinylated anti-rabbit IgG antibody and $\mathrm{ABC}$-AmP reagent (VECTASTAIN ABC-AmP Kit for rabbit IgG, Vector Laboratories) according to the manufacturer's protocol. Specific bands on the membrane were visualized using the BCIP/NBT chromogenic substrate (Vectastain ABC-AmP Kit, Vector Laboratories), detected with the Bio-Rad Universal Hood II (Bio-Rad Laboratories, Hercules, CA, USA) and the specific color densities of the bands were quantified with the Bio-Rad Quantity One software (Bio-Rad Laboratories) (Fig. 1). For statistical evaluation, the color intensity of PPAR $\gamma$ bands clustered pixels were set in relation to the $\beta$-actin bands clustered pixels. The western blots were repeated independently five times. 


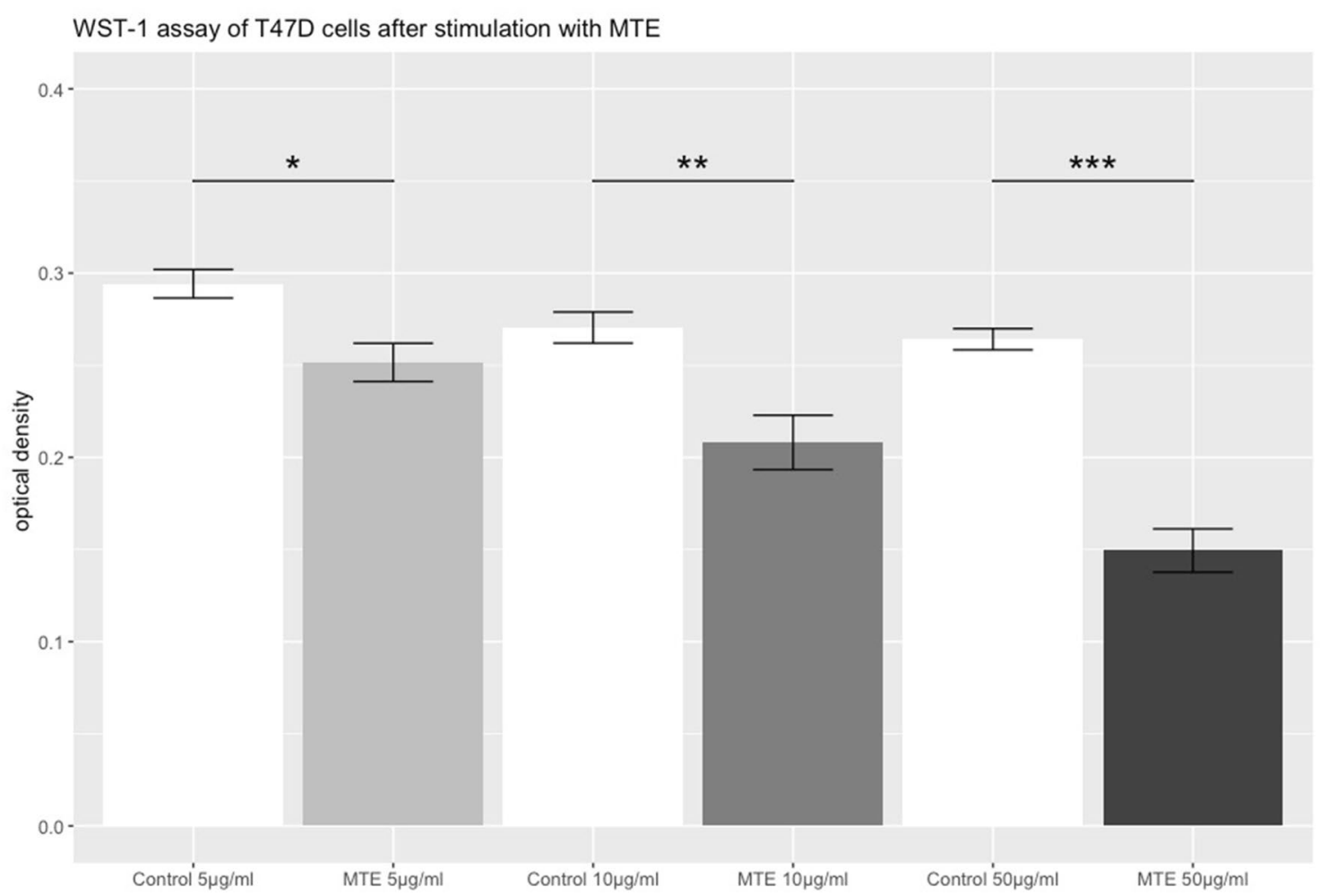

Fig. 2 WST-1 assay of T47D cells stimulated with MTE. The grey bars represent the optical density of T47D cells after the incubation with different concentrations of MTE $(5,10$ and $50 \mu \mathrm{g} / \mathrm{ml})$ for $72 \mathrm{~h}$. The white bars represent the control group. The top of each bar rep-

\section{Statistical analysis}

The statistical programming environment $R$, version 4.0.2 [36], was used for processing and statistical analysis of the collected data. Findings with $p$ values $<0.05$ were considered significant. Shapiro-Wilk tests were used to check normality of distributions. Adapted to the specific design of experiment we applied different statistical tests to compare stimulated and control samples. The paired $t$ test was used for the WST-1 and PCR assay. To account for repeated measurements in several Western-blot analyses we fitted a linear random effects model.

\section{Results}

\section{WST-1 proliferation assay}

To detect changes in T47D cellular viability after incubation, a WST-1 proliferation assay was performed. A significant inhibitory effect in cell viability was observed $(p=0.017)$ already at the concentration of $5 \mu \mathrm{g} / \mathrm{ml}$ MTE. As the concentrations of MTE increased, higher levels of significance resents the mean \pm standard error (SE). MTE induced a significant reduction of cell proliferation at every concentration. Significant results are linked and marked with asterisks $\left(p<0.05^{*}, p<0.01^{* *}\right.$, $\left.p<0.001^{* * *}\right)$

where observed (10 $\mu \mathrm{g} / \mathrm{ml}$ MTE: $p=0.002 ; 50 \mu \mathrm{g} / \mathrm{ml}$ MTE: $p<0.001)$. Results are shown in Fig. 2.

\section{PCR for PPARy expression on mRNA level}

To detect changes of PPAR $\gamma$ mRNA expression after incubation of T47D cells with different MTE concentration, TaqMan ${ }^{\circledR}$ PCR was performed. To analyze the results, the comparative $2^{-\Delta \Delta \mathrm{Cq}}$ method was used. The $x$ fold expression of mRNA in comparison to the control increased in a dosedependent manner. Whereas at the concentrations of $5 \mu \mathrm{g} /$ $\mathrm{ml}$ and $10 \mu \mathrm{g} / \mathrm{ml} \mathrm{mRNA}$ expression of PPAR $\gamma$ was numerically higher than control, this increase was only statistically significant at the highest concentration of $50 \mu \mathrm{g} / \mathrm{ml}$ MTE $(5 \mu \mathrm{g} / \mathrm{ml} \mathrm{MTE}: p=0.539 ; 10 \mu \mathrm{g} / \mathrm{ml}$ MTE: $p=0.163 ; 50 \mu \mathrm{g} /$ ml MTE: $p=0.029$ ). Results are shown in Fig. 3.

\section{Western blot for PPARy on protein level}

To investigate PPAR $\gamma$ expression on a protein level, a western blot was applied. At all MTE concentrations PPAR $\gamma$ expression increased in a dose-dependent manner in comparison to the control cells. PPAR $\gamma$ expression was significantly elevated at MTE concentrations of 10 and $50 \mu \mathrm{g} / \mathrm{ml}$ 


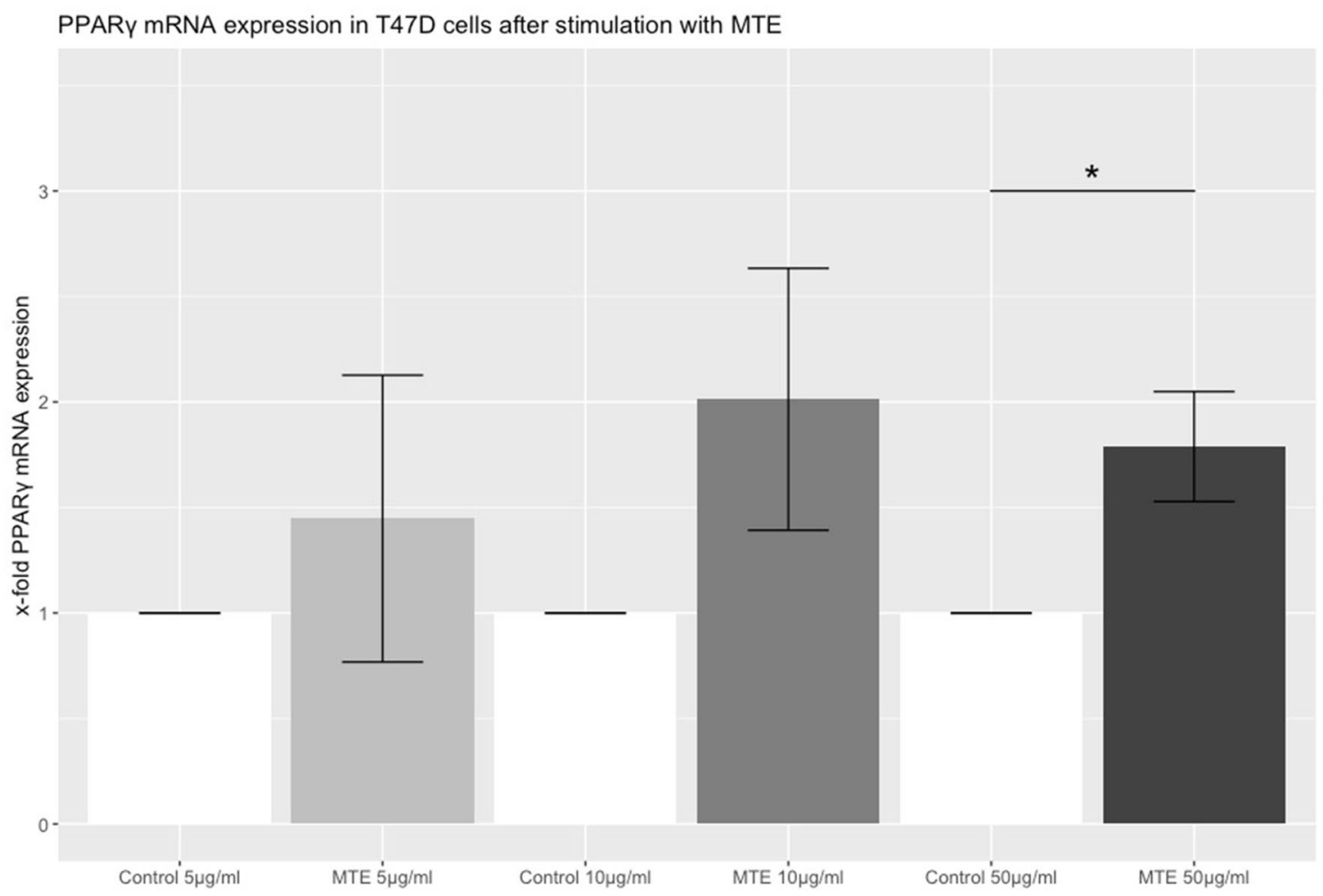

Fig. 3 The bar chart represents the relative PPAR $\gamma$ expression on mRNA level in T47D cells after incubation with three different concentrations of MTE $(5,10$ and $50 \mu \mathrm{g} / \mathrm{ml})$ or the control solution for 2 h. mRNA levels were detected via TaqMan ${ }^{\circledR}$ real-time PCR. The

(5 $\mu \mathrm{g} / \mathrm{ml}$ MTE: $p=0.315 ; 10 \mu \mathrm{g} / \mathrm{ml}$ MTE: $p<0.001 ; 50 \mu \mathrm{g} /$ ml MTE: $p<0.001)$. Results are shown in Fig. 4.

\section{Discussion}

To our knowledge, this is the first study investigating the effect of MTE on PPAR $\gamma$ expression in T47D breast cancer cells. Natural substances have a long history in the prevention and treatment of neoplasms [37]. Green tea and matcha tea-with their chemical compounds including vitamins, phenolic acids, quercetin and catechins-have been associated with health benefits such as anti-inflammatory and anti-carcinogenic effects [38]. EGCG is the most abundant catechin in matcha tea. Its potent growth inhibitory effects have been demonstrated in various cell lines [39, 40]. A possible anti-carcinogenic effect of EGCG on the estrogen receptor positive, HER2 negative, T47D cell line has been investigated in the past yielding controversial results. While Moradzadeh et al. were able to demonstrate decreased cell viability after treatment with EGCG [31], Zeng et al. could not find an anti-carcinogenic effect of EGCG on T47D cells alone [32]. We therefore wanted to investigate the potential antiproliferative effects and effects on PPAR $\gamma$ expression values on the $y$ axis are show ratios of stimulated and control expression levels. The top of each bar represents the mean \pm SE. Statistical significance was achieved at the highest concentration of MTE $(p=0.029)$ and is marked with one asterisks

of matcha tea extract on T47D cells. In this study, we used an extract instead of its individual active compounds to evaluate the cumulative and synergistic anti-carcinogenic effect of all active compounds in MT. In previous studies, we could demonstrate anti-carcinogenic effects on both ER/ $\mathrm{PR}$ receptor-positive and -negative breast cancer cells using GT, MT, EGCG and quercetin [40]. Our hypothesis in this trial was that PPAR $\gamma$ induction may be responsible for some of the observed anti-carcinogenic effects.

It has been proposed that MTT/MTS-based assays may underestimate an antiproliferative effect of EGCG. EGCG has been described to induce an increased activity of the mitochondrial dehydrogenase and furthermore has an intrinsic potential to reduce MTT and MTS and therefore increase the formation of formazan [41-43]. The significant reduction in cell growth by all used concentrations underlines the anti-carcinogenic effect of matcha tea extract on T47D cells in vitro. The main limitations of the methods used in this in vitro study are the use of concentrations not achievable in vivo by oral ingestion of MT and that MTE has not been subjected to prior digestion, intestinal absorption, and first pass metabolism. In 1997, Nagakawa and Miyazawa demonstrated that due to the complexity of digestion, absorption and metabolism, the maximum serum plasma concentration 


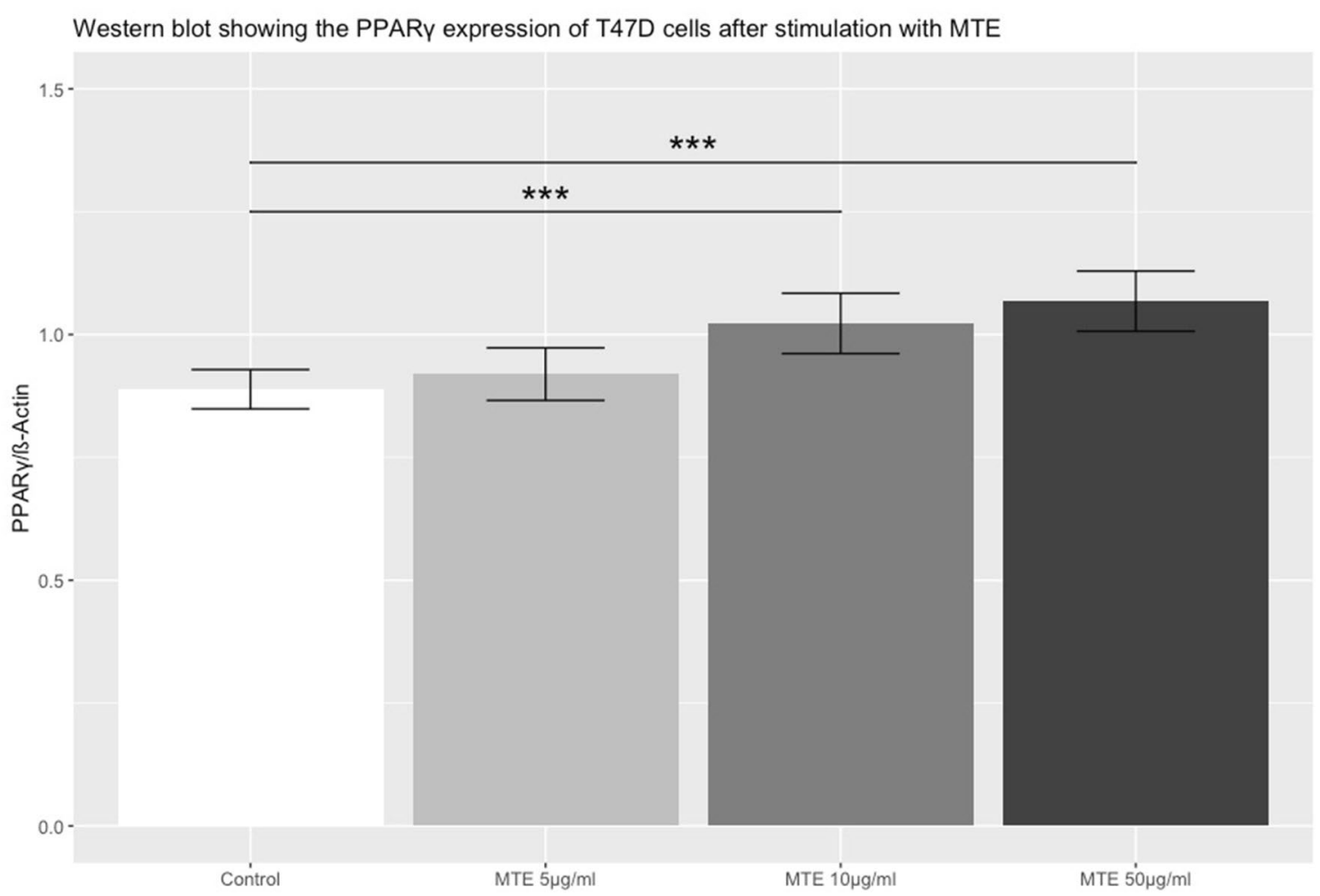

Fig. 4 The bar chart shows the PPAR $\gamma$ protein expression in T47D cells after stimulation with different concentrations of MTE compared to control. The top of each bar represents the mean \pm SE. MTE induced a significant upregulation of PPAR $\gamma$ expression on protein

of EGCG is only $0.024 \%$ of the amount ingested [10]. In a study by Yang et al. 18 individuals consumed $3 \mathrm{~g}$ of decaffeinated GT (EGCG content: $73 \mathrm{mg} / \mathrm{g}$ ) which resulted in an EGCG plasma concentration of no more than $326 \mathrm{ng} / \mathrm{ml}$. Whereas higher amounts of GT consumption $(4.5 \mathrm{~g})$ did not lead to increased plasma concentrations, an increase from 1.5 to $3 \mathrm{~g}$ resulted in a triple EGCG plasma concentration [44]. The lowest concentration used in our study was $5 \mu \mathrm{g} /$ $\mathrm{ml}$, equal to $5000 \mathrm{ng} / \mathrm{ml}$ MTE. Weiss et al. described concentrations of EGCG after extraction with water of $0.32 \mathrm{mg}$ per gram of MT [45]. Transferring these findings, the amount of EGCG at the given concentrations of 5, 10 and $50 \mu \mathrm{g} / \mathrm{ml}$ are higher than those that are achievable by oral ingestion of MT. EGCG metabolism such as methylation, glucuronidation, sulfation, and oxidative degradation further weakens its efficacy. For example, the catechol- $O$-methyltransferase (COMT) reduces the amount of EGCG available. Carriers of the lesser potent COMT-L allele benefit more from catechin activity than carriers of the highly potent COMT-H allele [46]. To overcome low bioavailability, several different approaches have been investigated. A simple method is the application of EGCG capsules where dosages of $800 \mathrm{mg}$ resulted in plasma levels of up to $439 \mathrm{ng} / \mathrm{ml} \mathrm{[47].}$ Approaches that are more complex include modification of level at MTE concentrations of $10 \mu \mathrm{g} / \mathrm{ml}$ and $50 \mu \mathrm{g} / \mathrm{ml}$. Significant differences between groups are linked and marked with asterisks $(p<0.001 * * *)$

the EGCG molecule. For example, it has been demonstrated that the addition of peracetate protections to EGCG hydroxy groups leads to higher bioavailability and higher concentrations in breast cancer cells [48]. Moreover, recently several different advanced nanovehicle-enabled delivery systems of EGCG have been tested in various cell and animal models that demonstrate better bioavailability and promising results in the context of cancer therapy [49]. Due to the facts described above, it becomes clear that although relevant results regarding PPAR $\gamma$ induction were demonstrated, this in vitro study cannot simulate the conditions encountered in human physiology. Animal studies might provide more insight.

Despite the methodological limitations mentioned above, the strength of our study lies in the fact that while many in-vitro studies have until now extensively investigated steroid receptor interaction and resulting downstream cellular cascades after MT and EGCG incubation, our study has demonstrated a different target of phenol action in T47D breast cancer cells: the PPAR $\gamma$ receptor. Clinical studies have identified PPAR $\gamma$ expression as a positive prognostic factor in ductal breast cancer [50] and higher concentrations of PPAR $\gamma$ seem to correlate inversely with grading, size and TNM stage of breast 
cancer [51, 52]. Until now, studies investigating a potential association between PPAR $\gamma$ and the anti-carcinogenic effect of MTE on breast cancer cells are lacking. Therefore, we investigated the PPAR $\gamma$ expression on protein and mRNA level after being exposed to matcha tea extract at concentrations of 5,10 , and $50 \mu \mathrm{g} / \mathrm{ml}$ ). With the use of western blots, we could demonstrate a positive correlation between PPAR $\gamma$ expression and an increase in MTE concentration. Similar results emerged at the mRNA level, where an increased concentration of MTE leads to higher expression rates of PPAR $\gamma$, but statistical significance was only reached at the highest MTE concentration.

As a nuclear receptor, the activity of PPAR $\gamma$ is depending on its intracellular localization and the activation through ligands, which can be natural agonists like fatty acids or prostanoids or synthetic ones like thiazolidinedione drugs [29]. Current data from in vitro and in vivo studies suggest an involvement of PPAR $\gamma$ in various cell signaling pathways. Via the stimulation of PPAR $\gamma$ ligands an upregulation of the expression of syndecan- 1 and the activation of FAS ligand has been reported, which lead to an induction of cell apoptosis [53, 54]. Moreover, ligand activated PPAR $\gamma$ can interfere in the regulation of cell growth and cell cycle via the activation of promoter gene p53 and the upregulation of p53 and the target gene p21 [55]. This also triggers the intrinsic apoptotic pathway. Of special interest regarding a possible interference between PPAR $\gamma$ and the cell growth inhibitory effects induced by the compounds of matcha tea is the downregulation of the cyclin D1 promoter by PPAR $\gamma$ ligands. The reduced expression leads to the induction of a cell cycle arrest [56, 57]. Hong et al. could demonstrate that treatment of breast cancer cells with EGCG also leads to an inhibition of growth via downregulation of $\beta$-catenin, phosphorylated Akt and cyclin D1 [58]. With the dose dependent anti-carcinogenic effect and simultaneous upregulation of PPAR $\gamma$, the influence of PPAR $\gamma$ via the downregulation of cyclin D1 seems plausible.

As our study seems to be one of the first investigating a potential involvement of PPAR $\gamma$ in the anti-carcinogenic effect of MTE in breast cancer, there is a lack of evidence regarding the alteration of cellular pathways. Moreover, as we analyzed an extract, the substrate responsible for the observed results still remains unknown. From other experiments of our group, we know that matcha tea also contains fatty acids, which could be responsible for PPAR $\gamma$ upregulation. In the future the experiment could be repeated with EGCG and fatty acids to evaluate their effects. In addition, decreased viability of T47D cells after MTE stimulation could be investigated in detail by immunohistochemistry or reverse transcriptase quantitative (RTQ)-PCR quantification of apoptosis-induced markers (for example, p53, p21, BCL2, Caspase 8/9). MTE incubation of estrogen receptor negative breast cancer cells (e.g. BT-20) could evaluate the effect of possible estrogen receptor interaction. Finally, our results may serve as a motivation for further investigations on matcha tea induced PPAR $\gamma$ alterations in cancer cell or animal models.

\section{Conclusions}

In this in vitro study, we could demonstrate that incubation of T47D cells with different concentrations of MTE results in an increased expression of PPAR $\gamma$ and a dose dependent reduction of cellular viability. As PPAR $\gamma$ expression can result in anti-carcinogenic effects, more research in this field is needed to evaluate the observed results.

Acknowledgements We want to thank everybody involved in realizing the project. Special thanks to Constantin Tilgener and Simone Hofmann for their laboratory work.

Author contributions S K: manuscript writing/editing, Data analysis; C $\mathrm{T}$ : data collection or management, protocol/project development; $\mathrm{U} \mathrm{J}$ : protocol/project development, data analysis, supervision; $\mathrm{S} \mathrm{H}$ : data collection or management, protocol/project development; $\mathrm{T} \mathrm{V}$ : manuscript writing/editing; T K: manuscript writing/editing; $\mathrm{H} \mathrm{H}$ : manuscript writing/editing; F B: manuscript writing/editing; S M: project supervision; L S: protocol/project development, manuscript writing/editing.

Funding Open Access funding enabled and organized by Projekt DEAL.

Availability of data and materials The datasets used and analyzed during the study are available from the corresponding author on request.

\section{Declarations}

Conflict of interest S. Mahner has received research support, advisory board, honoraria and travel expenses from AstraZeneca, Clovis, Eisai, GlaxoSmithKline, Medac, MSD, Novartis, Olympus, PharmaMar, Roche, Sensor Kinesis, Teva and Tesaro. All other authors declare to have no conflict of interest.

Consent for publication All authors have analyzed and interpreted the data and read and agreed to the published version of the manuscript.

Ethics approval Not applicable.

Open Access This article is licensed under a Creative Commons Attribution 4.0 International License, which permits use, sharing, adaptation, distribution and reproduction in any medium or format, as long as you give appropriate credit to the original author(s) and the source, provide a link to the Creative Commons licence, and indicate if changes were made. The images or other third party material in this article are included in the article's Creative Commons licence, unless indicated otherwise in a credit line to the material. If material is not included in the article's Creative Commons licence and your intended use is not permitted by statutory regulation or exceeds the permitted use, you will need to obtain permission directly from the copyright holder. To view a copy of this licence, visit http://creativecommons.org/licenses/by/4.0/. 


\section{References}

1. Glass AG et al (2007) Breast cancer incidence, 1980-2006: combined roles of menopausal hormone therapy, screening mammography, and estrogen receptor status. J Natl Cancer Inst 99(15):1152-1161

2. F Bray et al. (2018) Global cancer statistics GLOBOCAN estimates of incidence and mortality worldwide for 36 cancers in 185 countries (1542-4863 (Electronic)).

3. Harbeck N et al (2019) Breast cancer. Nat Rev Dis Prim 5(1):66

4. Wolf A, Bray GA, Popkin BM (2008) A short history of beverages and how our body treats them. Obes Rev 9(2):151-164

5. Maeda-Yamamoto $M$ et al (2011) Effect of green tea powder (Camellia sinensis L. cv. Benifuuki) particle size on O-methylated EGCG absorption in rats the kakegawa study. Cytotechnology 63(2):171-179

6. Koláčková T et al (2020) Matcha tea: analysis of nutritional composition, phenolics and antioxidant activity. Plant Foods Hum Nutr 75(1):48-53

7. Tachibana H (2009) Molecular basis for cancer chemoprevention by green tea polyphenol EGCG. Food Factors Health Promot 61:156-169

8. Belitz H-D, Grosch W, Schieberle P (2009) Coffee tea cocoa. Food Chemistry. Springer, Berlin, Heidelberg. https://doi.org/10.1007/ 978-3-540-69934-7_22

9. Stangl V, Lorenz M, Stangl K (2006) The role of tea and tea flavonoids in cardiovascular health. Mol Nutr Food Res 50(2):218-228

10. Nakagawa K, Miyazawa T (1997) Absorption and distribution of tea catechin,(-)-epigallocatechin-3-gallate, in the rat. J Nutr Sci Vitaminol 43(6):679-684

11. Dai W et al (2020) Bioavailability enhancement of EGCG by structural modification and nano-delivery: A review. J Funct Foods 65:103732

12. Nagle DG, Ferreira D, Zhou Y-D (2006) Epigallocatechin-3-gallate (EGCG): chemical and biomedical perspectives. Phytochem 67(17):1849-1855

13. Gupta S, Hussain T, Mukhtar H (2003) Molecular pathway for (-)-epigallocatechin-3-gallate-induced cell cycle arrest and apoptosis of human prostate carcinoma cells. Arch Biochem Biophys 410(1):177-185

14. Sartippour MR et al (2001) Green tea and its catechins inhibit breast cancer xenografts. Nutr Cancer 40(2):149-156

15. Ogunleye AA, Xue F, Michels KB (2009) Green tea consumption and breast cancer risk or recurrence: a meta-analysis. Breast Cancer Res Treat 119(2):477

16. S.F Eddy G E Kane Se Fau-Sonenshein G E Sonenshein Trastuzumab-resistant HER2-driven breast cancer cells are sensitive to epigallocatechin-3 gallate (0008-5472 (Print)).

17. Yamakawa S et al (2004) (-)-Epigallocatechin gallate inhibits membrane-type 1 matrix metalloproteinase, MT1-MMP, and tumor angiogenesis. Cancer Lett 210(1):47-55

18. J Kim et al. Suppression of Wnt signaling by the green tea compound (-)-epigallocatechin 3-gallate (EGCG) in invasive breast cancer cells Requirement of the transcriptional repressor HBP1. (0021-9258 (Print)).

19. Yong Feng W (2006) Metabolism of green tea catechins: an overview. Curr Drug Metab 7(7):755-809

20. Mao JT et al (2010) White tea extract induces apoptosis in nonsmall cell lung cancer cells: the role of peroxisome proliferatoractivated receptor- $\gamma$ and 15-lipoxygenases. Cancer Prev Res 3(9):1132-1140

21. Zhang S et al (2014) PPAR $\alpha$ activation sensitizes cancer cells to epigallocatechin-3-gallate (EGCG) treatment via suppressing heme oxygenase-1. Nutr Cancer 66(2):315-324
22. Danesi F et al (2008) Green tea extract selectively activates peroxisome proliferator-activated receptor $\beta / \delta$ in cultured cardiomyocytes. Br J Nutr 101(12):1736-1739

23. Spiegelman BM (1998) PPAR-gamma: adipogenic regulator and thiazolidinedione receptor. Diabetes 47(4):507-514

24. Yki-Järvinen H (2004) Thiazolidinediones. N Engl J Med 351(11):1106-1118

25. Koeffler HP (2003) Peroxisome proliferator-activated receptor $\gamma$ and cancers. Clin Cancer Res 9(1):1-9

26. Girnun GD et al (2002) APC-dependent suppression of colon carcinogenesis by PPAR $\gamma$. Proc Natl Acad Sci 99(21):13771-13776

27. Saez E et al (2004) PPAR $\gamma$ signaling exacerbates mammary gland tumor development. Genes Dev 18(5):528-540

28. Saez E et al (1998) Activators of the nuclear receptor PPAR $\gamma$ enhance colon polyp formation. Nat Med 4(9):1058-1061

29. Augimeri $\mathrm{G}$ et al (2020) The role of PPAR $\gamma$ ligands in breast cancer: from basic research to clinical studies. Cancers 12(9):2623

30. Elstner E et al (1998) Ligands for peroxisome proliferator-activated receptor $\gamma$ and retinoic acid receptor inhibit growth and induce apoptosis of human breast cancer cells in vitro and in BNX mice. Proc Natl Acad Sci 95(15):8806-8811

31. Moradzadeh M et al (2017) Epigallocatechin-3-gallate promotes apoptosis in human breast cancer T47D cells through down-regulation of PI3K/AKT and telomerase. Pharmacol Rep 69(5):924-928

32. Zeng L, Holly JMP, Perks CM (2014) Effects of physiological levels of the green tea extract epigallocatechin-3-gallate on breast cancer cells. Front Endocrinol 5:61

33. Brunner D et al (2010) The serum-free media interactive online database. ALTEX-Altern anim exp 27(1):53-62

34. van der Valk J et al (2018) Fetal bovine serum (FBS): past-present-future. Altex 35(1):1-20

35. Livak KJ, Schmittgen TD (2001) analysis of relative gene expression data using real-time quantitative pcr and the $2-\Delta \Delta \mathrm{CT}$ method. Methods 25(4):402-408

36. R Core Team (2020) R A language and environment for statistical computing R Foundation for Statistical Computing Vienna Austria https://www.R-project.org/.

37. Surh Y-J (2003) Cancer chemoprevention with dietary phytochemicals. Nat Rev Cancer 3(10):768-780

38. Kochman J et al (2021) Health benefits and chemical composition of matcha green tea: a review. Molecules 26(1):85

39. Braicu $\mathrm{C}$ et al (2015) Dual targeted therapy with p53 siRNA and Epigallocatechingallate in a triple negative breast cancer cell model. PLoS ONE 10(4):e0120936

40. Schröder L et al (2019) Effects of green tea, matcha tea and their components epigallocatechin gallate and quercetin on MCF-7 and MDA-MB-231 breast carcinoma cells. Oncol Rep 41(1):387-396

41. Wang P, Henning SM, Heber D (2010) Limitations of MTT and MTS-based assays for measurement of antiproliferative activity of green tea polyphenols. PLoS ONE 5(4):e10202

42. Hsu S et al (2003) Green tea polyphenols induce differentiation and proliferation in epidermal keratinocytes. J Pharmacol Exp Ther 306(1):29-34

43. Bruggisser R et al (2002) Interference of plant extracts, phytoestrogens and antioxidants with the MTT tetrazolium assay. Planta Med 68(05):445-448

44. Yang CS et al (1998) Blood and urine levels of tea catechins after ingestion of different amounts of green tea by human volunteers. Cancer Epidemiol Prev Biomark 7(4):351-354

45. Weiss DJ, Anderton CR (2003) Determination of catechins in matcha green tea by micellar electrokinetic chromatography. J Chromatogr A 1011(1-2):173-180

46. Wu AH et al (2003) Tea intake, COMT genotype, and breast cancer in Asian-American women. Can Res 63(21):7526-7529 
47. Chow HHS et al (2003) Pharmacokinetics and safety of green tea polyphenols after multiple-dose administration of epigallocatechin gallate and polyphenon $\mathrm{E}$ in healthy individuals. Clin Cancer Res 9(9):3312-3319

48. Landis-Piwowar KR et al (2007) A novel prodrug of the green tea polyphenol (-)-epigallocatechin-3-gallate as a potential anticancer agent. Can Res 67(9):4303-4310

49. Li K, Teng C, Min Q (2020) Advanced nanovehicles-enabled delivery systems of epigallocatechin gallate for cancer therapy. Front Chem 8:874

50. Papadaki I et al (2005) PPAR $\gamma$ expression in breast cancer: clinical value and correlation with ER $\beta$. Histopathol 46(1):37-42

51. Jiang $Y$ et al (2009) PPAR $\gamma$ and $\mathrm{Wnt} / \beta$-Catenin pathway in human breast cancer: expression pattern, molecular interaction and clinical/prognostic correlations. J Cancer Res Clin Oncol 135(11):1551-1559

52. Abduljabbar R et al (2015) Prognostic and biological significance of peroxisome proliferator-activated receptor-gamma in luminal breast cancer. Breast Cancer Res Treat 150(3):511-522

53. Sun $\mathrm{H}$ et al (2008) Peroxisome proliferator-activated receptor $\gamma$-mediated up-regulation of syndecan- 1 by $n-3$ fatty acids promotes apoptosis of human breast cancer cells. Can Res 68(8):2912-2919

54. Bonofiglio D et al (2009) Peroxisome proliferator-activated receptor gamma activates fas ligand gene promoter inducing apoptosis in human breast cancer cells. Breast Cancer Res Treat 113(3):423-434

55. Bonofiglio D et al (2006) Peroxisome proliferator-activated receptor- $\gamma$ activates p53 gene promoter binding to the nuclear factor- $\kappa \mathrm{B}$ sequence in human MCF7 breast cancer cells. Mol Endocrinol 20(12):3083-3092

56. Wang $C$ et al (2001) Inhibition of cellular proliferation through IкB kinase-independent and peroxisome proliferator-activated receptor $\gamma$-dependent repression of cyclin D1. Mol Cell Biol 21(9):3057-3070

57. Yin F et al (2001) Troglitazone inhibits growth of MCF-7 breast carcinoma cells by targeting G1 cell cycle regulators. Biochem Biophys Res Commun 286(5):916-922

58. Hong OY et al (2017) Epigallocatechin gallate inhibits the growth of MDA-MB-231 breast cancer cells via inactivation of the $\beta$-catenin signaling pathway. Oncol Lett 14(1):441-446

Publisher's Note Springer Nature remains neutral with regard to jurisdictional claims in published maps and institutional affiliations. 